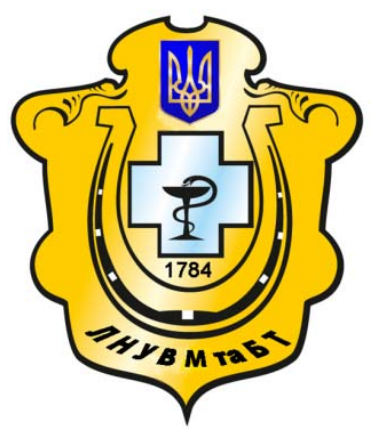

Науковий вісник Львівського національного університету ветеринарної медицини та біотехнологій імені С.З. Гжицького

Scientific Messenger of Lviv National University of Veterinary Medicine and Biotechnologies named after S.Z. Gzhytskyj

doi:10.15421/nvlvet7604

ISSN 2519-2701 print

ISSN 2518-1327 online

http://nvlvet.com.ua/

\title{
Використання криптовалют в сучасних економічних системах України: перспективи та ризики
}

\author{
С.В. Васильчак ${ }^{1}$, М.В. Куницька-Іляш ${ }^{2}$, М.П. Дубина ${ }^{2}$ \\ dubynamarichka@gmail.com \\ ${ }^{1}$ Львівський державний університет внутрішніх справ, \\ вул. Городоцька, 26, м. Львів, 79007, Украӥна; \\ ${ }^{2}$ Львівський національний університет ветеринарної медицини та біотехнологій імені С.3. Гжииького, \\ вул. Пекарська, 50, м. Львів, 79010, Україна \\ «Гроші - головний стержень навколо якого сконщентрована економічна наука». А. Мариалл
}

Досліджено розвиток та використання в Украйні інновачійних технологій розрахунків, а саме криптовалюти. Проаналізовано особливості функиіонування криптовалют у світових платіжних системах. Криптовалюта як абсолютно інноваційний платіжний інструмент в сучасних умовах розвитку комп'ютерних технологій, значно інтегрується у повсякденне життя людей, тому питання розвитку та використання цьвого платіжного засобу в Украйні набуває особливого значення. Відбувається це на фоні кризи вітчизняної банківської системи, нестабільності національної валюти, мінливого курсу валют та інших труднощів, які постають перед економічними суб'єктами. Однак, поряд з перевагами, криптовалюта має також і певні недоліки, які стримують ї̈ розвиток та використання в Україні. Аналіз недоліків здійснений в даній статті. Дослідження міжнародної практики використання криптовалюти свідчить про те, що у світі неоднозначно ставляться до її впровадження в обіг, а пояснюється ие в периу чергу новизною даного платіжного інструменту та відсутністю єдиного визначення категорії «криптовалюта», яка б розкривала ї̈ економічну сутність. Основним об'єктом дослідження в даній статті є bitcoin. Bitcoin успішно виконує функиію грошей у відносинах, які виникають в процесі суспільного виробництва між людьми по всьому світу. Передача bitcoin здійснюється безпосередньо між платником та отримувачем через децентралізовану (пірингову р2p) мережу. У иій схемі передачі біткоӥнів немає посередників, які зазвичай встановлюють свої правила, мають змогу блокувати та обмежувати. Сьогодні Віtсоіп - сучасна цифрова валюта, яка чудово підходить для розрахунків в мережі Інтернет. Також розглянуто питання інвестицій у реальний сектор економіки за допомогою криптовалют, використання в економічі країни та спроби їх регулювання. Сьогодні в світі налічується близько 1,6 тис. віртуальних валют. Понад 600 серед них є активними, а ринкова вартість 30 валют понад 1 млрд дол. США.

Bitcoin залишаються найпоширенішими та найдорожчими, вони не випускаються центральними банками $і$ не залежать від грошово-кредитної політики держави. Їхня максимальна кількість лімітована, а тому інфляція їм не загрожує.

Ключові слова: криптовалюта, волатильність, bitcoin, блокчейн, валюта, електронні гаманиі, електронні платежі, електронні гроші, інституалізація, капіталізація, майнінг, цифрова (віртуальна) валюта, майнери.

\section{Использование криптовалют в современных экономических системах Украины: перспективы и риски}

\author{
С.В. Васильчак ${ }^{1}$, М.В. Куницкая-Ильяш ${ }^{2}$, М.П. Дубина ${ }^{2}$ \\ dubynamarichka@gmail.com \\ ${ }^{1}$ Львовский государственный университет внутренних дел, \\ ул. Городочкая, 26, Львов, 79007, Украина; \\ ${ }^{2}$ Львовский нацииональный университет ветеринарной медицины и биотехнологий имени С.3. Гжицукого, \\ ул. Пекарская, 50, г. Львов, 79010, Украина;
}

Citation:

Vasylchak, S.V., Kunytska-Ilyash, M.V., Dubyna, M.P. (2017). Using of cryptocurrency in the modern economic systems of Ukraine: prospects and risks. Scientific Messenger LNUVMBT named after S.Z. Gzhytskyj, 19(76), 19-25. 
Исследовано развитие и использование в Украине инновационных технологий расчетов, а именно криптовалюти. Проанализированы особенности функиионирования криптовалют в мировых платежных системах. Криптовалюта, как абсолютно инновационный платежный инструмент, в современных условиях развития компьютерных технологий, значительно интегрируется в повседневную жизнь людей, потому вопрос развития и использования этого платежного средства в Украине приобретает особое значение. Однако, рядом с преимуществами, криптовалюта имеет такље и определеннье недостатки, которые сдерживают ее развитие и использование в Украине. Основным объектом исследования в данной статье является bitcoin. Bitcoin успешно выполняет функцию денег в отношениях, которые возникают в процессе общественного производства между людьми по всему миру. Сегодня Bitcoin - современная цицфровая валюта, которая замечательно подходит для расчетов в сети Интернет. Также рассмотрен вопрос инвестиций в реальньй сектор экономики с помощьью криптовалют, использование в экономике страны и попытки их регуляции. Вітсоіп остаются самыми распространенными и самыми дорогими, они не выпускаются центтральными банками и не зависят от денежно-кредитной политики государства. Их максимальное количество лимитировано, а потому инфляция им не угрожает.

Ключевые слова: криптовалюта, волатильность, bitcoin, блокчейн, валюта, электронные кошельки, электронные платежи, электронные деньги, институализация, капитализация, майнинг, циифровая (виртуальная) валюта, майнер.

\title{
Using of cryptocurrency in the modern economic systems of Ukraine: prospects and risks
}

\author{
S.V. Vasylchak ${ }^{1}$, M.V. Kunytska-Ilyash ${ }^{2}$, M.P. Dubyna ${ }^{2}$ \\ dubynamarichka@gmail.com \\ ${ }^{1}$ Lviv State University of Internal Affairs, \\ Horodotska Str., 26, Lviv, 79007,Ukraine; \\ ${ }^{2}$ Lviv national university of veterinary medicine and biotechnologies named after S. Gzhytskyj, \\ Pekarska Str., 50, Lviv, 79010, Ukraine
}

This article explores the development and use of innovative technologies in Ukraine calculations, namely cryptocurrency. It was considered peculiarities of cryptocurrency in global payment systems. Cryptocurrency is a completely innovative payment tool in the development of modern computer technology, greatly integrated into everyday life, as well as the development and use of the payment instrument in Ukraine is particularly important. This occurs against the backdrop of the crisis the domestic banking system, currency instability, volatile exchange rates and other difficulties faced by business entities. However, along with the benefits cryptocurrency also has some drawbacks that hinder their development and use in Ukraine. Disadvantages mentioned in this article. This occurs against the backdrop of the crisis the domestic banking system, currency instability, volatile exchange rates and other difficulties faced by business entities. However, along with the benefits cryptocurrency also has some drawbacks that hinder their development and use in Ukraine. Disadvantages and advantages is mentioned in this article. The main object of study in this article is bitcoin. Bitcoin successfully performs the function of money in the relations arising in the process of social production between people worldwide. Bitcoin transfer is done directly between the payer and the payee through IT (equal P2P) network. In transfer of bitcoin agents are not usually set their own rules, are able to restrict the operation. Today Bitcoin - a modern digital currency, which is perfect for payments on the Internet. The question of investment in the real economy via cryptocurrency use of the economy and their regulation. Today there are about 1.6 thousand of virtual currencies. More than 600 of them are active, market value 30 currencies than one billion USA. Bitcoin remains the most common and the most expensive, they are not issued by central banks and are independent of monetary policy. Their amount is limited, so inflation does not threat them.

The article aims is to study the dynamics of today's economy cryptocurrency in Ukraine. Today using the cryptocurrency in the world as a completely new, innovative payment instrument of XXI century is becoming very popular, that's why the development and use of this means of payment needs further research in Ukraine.

Key words: cryptocurrency, volatility, bitcoin, blockchain, currencies, electronic wallets, electronic payments, electronic money, institutionalization, capitalization, mining, digital (virtual) currency trader.

\section{Ветуп}

Сучасні умови розвитку ринкових відносин в Україні та тї участь у світових глобалізаційних процесах зумовлюють необхідність зміцнення грошовокредитної системи, підвищення ефективності використання інструментів монетарної політики 3 метою посилення їхнього впливу на структуру перебудови та подальший розвиток економіки. Якщо аналізувати реалії соціально-економічного життя України, пріоритети вищих органів влади зосереджені на вирішенні гострих проблем у сфері фінансів. Це обгрунтовує актуальність дослідження сутності i механізму функціонування сучасних грошей, валютнокредитних відносин, операцій 3 криптовалютою та тенденціях розвитку електронних грошей. Адже у ринковій економіці фінансовий стан та конкурентоспроможність суб'єктів господарювання залежить від фінансової грамотності - вміння управляти грошовими потоками, кредитними ресурсами та оперувати сучасними грошима - криптовалютою. Немає нічого важливішого для розуміння механізмів функціонування ринкової економіки, ніж розуміння ролі грошей, що є іiї основним інструментом.

Гроші $є$ дуже важливим інструментом в економічній науці, оскільки особливого розвитку набувають операції відповідно до форм грошей. Свою форму гроші змінювали в процесі історичного розвитку. Головними видами функціональних форм грошей сьогодні є неповноцінні гроші: монети, паперові, кредитні (банкнота, вексель, чек), депозитні й електронні гроші (Krupka, 2011). 
Термін «електронні гроші» $\epsilon$ порівняно новим у науковій літературі, тому нема єдиного визнаного у світі визначення електронних грошей, яке б однозначно розкрило їхню сутність, і нема також чітких критеріїв віднесення новітніх платіжних продуктів до електронних грошей. Протягом кількох років у нашій країні діють системи розрахунків електронними грошима як на програмній основі, так і на підставі карток. Комплексна програма розвитку фінансового сектору України до 2020 року передбачає розвиток безготівкових платежів 3 використанням електронних грошей. Перспективним напрямом для України є запровадження концепції безготівкової економіки (cashless economy). Варто зазначити, що розвиток комп'ютерних технологій сприяє появі нової епохи «електронних грошей» і все частіше звучить термін «криптовалюта».

В даний час відбувається поширення обсягів використання криптовалюти в світі, як абсолютно нового, інноваційного платіжного інструменту XXI століття, тому питання розвитку та використання цього платіжного засобу в Україні потребують подальших досліджень.

Аналіз останніх досліджень $і$ публікащій. Дослідження криптовалюти розпочалося у 1980-ті роки, тому питання дослідження їх розвитку $є$ порівняно новим. Вивченню історії розвитку та функціонування криптовалют присвячені праці вчених, таких як Е. Андроулакі, С. Капкун, О. Караме, М. Роесчлін, T. Счереp (Androulaki et al., 2013; Gervais et al., 2015), М. Андручович, Д. Джіембовскі, Л. Мазурек (Andrychowicz et al., 2014), Д., М. Гражек, Н. Коуртоіс, Р. Наїк (Courtois et al., 2014), Г. Максвел (Maxwell, 2013), А. Герваїс, Д. Грубер (Gervais et al., 2015), О. Галицький, О. Мороз, Е. Молчанова, Ю. Солодковський. Однак проблематика дослідження розвитку криптовалют в Україні залишається недостатньо ви- вченою вітчизняними вченими, що й зумовлює актуальність наукових пошуків.

Метою даної статті є дослідження динаміки розвитку криптовалюти в сучасній економіці України.

\section{Результати та їх обговорення}

Останнім часом на фінансовому ринку з'явилися такі нові категорії, як «криптовалюта», «біткоїни», «блокчейни». Для більшості населення ці гроші нові та викликають багато питань. Криптовалюта - від англійського «cryptocurrency», тобто віртуальна валюта, захищена криптографією. Насамперед, криптовалюта - це швидка і надійна система платежів та грошових переказів, заснована на новітніх технологіях і непідконтрольна жодному уряду. На даний момент в світі існує близько 1600 криптовалют (Bitcoin, Litecoin, Ethereum, Peercoin), але найвідомішою зі швидким розвитком $\epsilon$ bitcoin. Bitcoin не випускаються центральними банками і не залежать від кредитногрошової політики тієї чи іншої держави. Емісія відбувається тільки в цифровому вигляді. Будь-хто охочий може добувати криптовалюту (займатися майнінгом), використовуючи комп'ютерні можливості. Запланована емісія криптовалюти не більше ніж 21 мільйона bitcoin, тому загалом випускається все менше і менше монет. За прогнозами майнерів у 2033 році емісія bitcoin досягне саме цієї позначки (Vartist Bitkoina...).

У 2015 році Європейський суд звільнив bitcoin від оподаткування, чим фактично визнав іiі повноцінною грошовою одиницею. Bitcoin - це своя власна валюта інтернету. Нею можна розраховуватись, і навіть зберігати як заощадження. Також інтерес до криптовалют створюють інвестиційні можливості. Курс криптовалюти bitcoin $є$ дуже волатильний, що можна побачити на рис. 1.

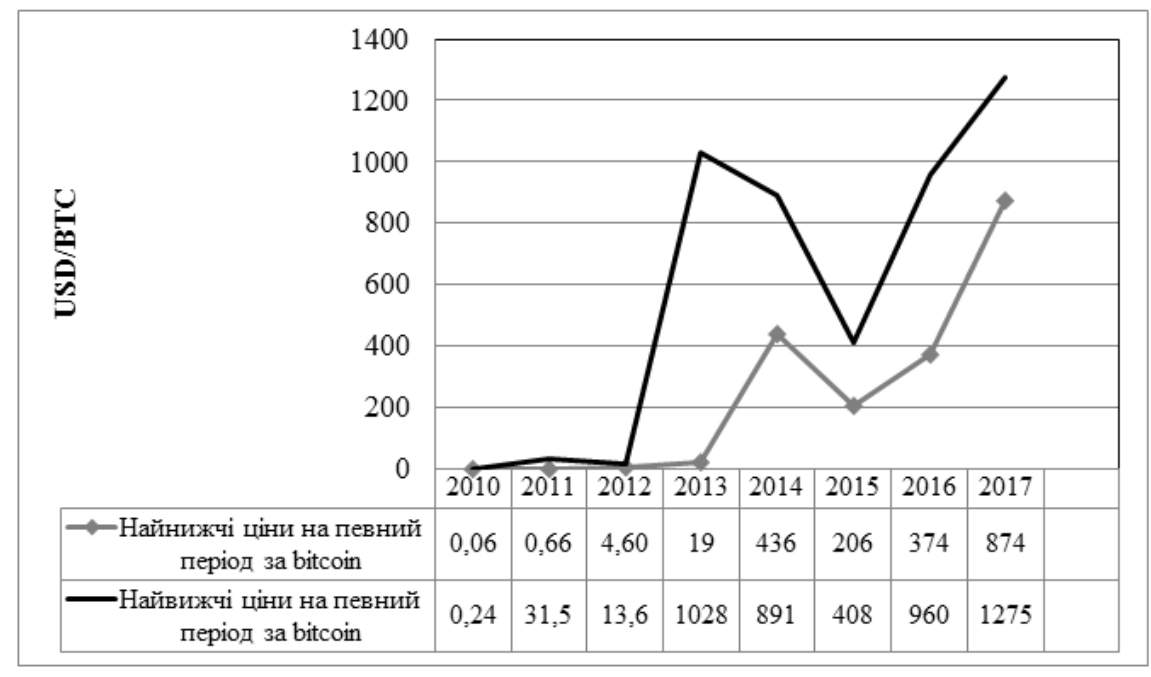

Рис. 1. Динаміка курсу долара до bitcoin протягом 2010-2017 pp.

Джерело: побудовано авторами на основі (Bitkoin v Ukraini...; Vartist Bitkoina zrosla do 1250 dolariv...; Skromna charivnist Bitkoina...)

На рис. 1 відображена динаміка коливання курсу bitcoin. На графічному зображенні ми бачимо найвигіднішу ціну для купівлі і продажу bitcoin на певний період (крива 1 найнижчі ціни, крива 2 найвижчі ціни). Аналізуючи даний графік можна зрозуміти, що коливання відбувається дуже різко, наприклад найнижчий курс 2011 року - 0,66 USD, а найвищий курс у 2011 році - 31,5 USD за bitcoin. У 2012 році в червні можна було купити bitcoin за 4,6 USD, а в листопаді продати за 13,6 USD. Розуміємо, що ті хто купили 
bitcoin у 2011 році за 31,5 USD втратили на одному bitcoin майже 18 USD. Але з 2013 року ціна за bitcoin почала стрімко зростати, якщо у червні купували bitcoin за 19,8 USD, то в листопаді ціна його зросла до 1028 USD. У 2014 році курс пішов на спад: червень - 891 USD, листопад - 436 USD за bitcoin. У 2015 році тенденція спаду продовжилася, в червні 2015 року bitcoin - 206 USD, але 3 листопада 2015 року за bitcoin віддавали 408 USD. На початку 2016 року bitcoin впав до 374 USD, але в листопаді його вартість становила 960 USD. За останні 6 років курс за bitcoin 3 позначки 0,66 USD зріс до позначки близько 1050 USD, а за останній місяць - він злетів більш ніж до 1275 USD за bitcoin (в 1931 разів). Таким чином, вартість цифрової валюти перевищила вартість унції золота. Ціна за одну тройську унцію золота (близько 31,1 г) 1237 USD. Одною з причин цього послужило зростання спекулятивного інтересу до цієї криптовалюти: дійсно, ті, хто зміг вчасно купити і вчасно продати bitcoin, змогли заробити великі гроші з невеликих сум.

У 2010 році вперше була проведена покупка реального товару за bitcoin. Тоді житель США купив 2 піци вартістю 50 доларів за 10000 bitcoin. Коли в листопаді 2013 року курс bitcoin досяг свого піку, ця людина написала в своєму блозі несамовитий пост про те, що якби не «проїв» свою криптовалюту, міг би зараз стати власником стану в 9 млн доларів. А студент з Норвегії в 2009 році купив 5000 біткоінів, витративши на операцію близько 27 доларів. У 2013 році він продав цю суму, виручивши 885000 доларів, тобто, збільшивши свій капітал за 4 роки майже в 33000 рази (Forum Bitcoin ...).

Але 3 урахуванням того, що первісна вартість bitcoin визначалася витратами електроенергії на його майнінг, можна робити висновок, що курс bitcoin все одно надмірно високий. Інший важливий момент, що забезпечує популярність bitcoin - це те, що він, по суті, $є$ вигідною і чесною альтернативою світовій фінансовій системі, яку багато хто вважає несправедливою і неефективною.

На сучасному етапі розвитку світової економіки використання криптовалюти значно розширюється, про що свідчить досвід закордонних партнерів.

Можна стверджувати, що Велика Британія є найбільш прогресивною країною відносно використання криптовалюти (тут нараховується більше, ніж 30 bitcoin-банкоматів). Данія відкрито заявила про бажання якнайшвидше ліквідувати паперові гроші, тому безготівкові розрахунки та цифрова валюта досить поширені. У березні 2016 року Данія стала першою скандинавською країною, де купівля нерухомості була здійснена за допомогою bitcoin.

Найсміливіше ставлення до криптовалюти продемонстрували Нідерланди, де було створено «місто bitcoin», де визначена найвища концентрація компаній, що надають товари та послуги за bitcoin. Тут можна не тільки сплатити юридичні послуги, а й підстригтися, купити гамбургер або новий костюм, надіслати листа, полагодити побутову техніку або зняти номер в готелі.
Міністерство фінансів Німеччини офіційно визнало bitcoin фінансовим інструментом та внесла відповідні зміни у Банківський кодекс. Франція, так само як і Україна, рекомендувала утриматися від використання bitcoin, Фінляндія розглядає bitcoin не як «валюту», а як «сировинний товар», Естонія відмовляється працювати 3 bitcoin, як і найбільший скандинавський SEB Bank. У США bitcoin розглядаються як один із засобів платежів в електронній комерції. Так, наприклад, найбільший американський інтернетмагазин побутової техніки Overstock.com давно функціонує за рахунок bitcoin. На Кіпрі один із університетів приймає цифрову валюту як спосіб оплати за навчання (Forum Bitcoin...)

В столиці Австрії Відні відкрився перший в світі bitcoin банк. Цей банк повинен зробити купівлю i продаж bitcoin простішим та безпечнішим. У банку встановлено спеціальні банкомати, які дозволяють обмінювати bitcoin на євро і навпаки. Клієнти банку також можуть отримати цікаву для них інформацію про віртуальні валюти. Проект став досить успішним, i після нього bitcoin банкомати стали з'являтися і в інших місцях.

Проте в таких країнах, як Росія, Еквадор, Киргизія, використання bitcoin було заборонено. У Китаї їх використання заборонено для фінансових інституцій (Skromna charivnist Bitkoina...).

В Японії був прийнятий закон, за яким 3 квітня цього року bitcoin та інші криптовалюти прирівнюються за статусом до фіатних грошей та стають законним платіжним засобом. Японія стала першою країною у світі, яка це зробила. Одним із поштовхів до надання криптовалютам статусу законного засобу платежу стали обвал торгів на одній 3 найбільших bitcoin-бірж MTGox та іï банкрутство у 2014 р., внаслідок чого іï клієнти зазнали величезних втрат, а курс криптовалюти сильно впав. Саме для того, щоб запобігти подібним ситуаціям та захистити права споживачів, Японія і здійснює законодавче врегулювання цього питання (Zakonodavcha nevrehulovanist prohresu).

Отже, міжнародна практика використання криптовалюти свідчить про те, що держави по-різному ставляться до іiі впровадження в обіг. Пояснюється це передусім новизною даного інструменту та відсутністю єдиного визначення категорії «криптовалюта», яка б розкривала іiі економічну сутність.

Зацікавленість до цифрових валют також і значно пожвавлюється в Україні. Спичиняє це криза вітчизняної банківської системи, нестабільність гривні, мінливий курс валют та інші соціально-економічні труднощі, які сконцентровані на фінансовій системі України. В Україні справжня популярність криптовалют розпочалася у 2014 році, коли ентузіастами було створено громадську організацію, що має на меті поширення, розвиток та вивчення bitcoin та інших віртуальних валют на території нашої держави Bitcoin Foundation Ukraine (BFU). Приблизно в цей час також почали з'являтись перші компанії та агенції, зокрема які пропонували фізичний обмін криптовалют за готівку, а також здійснення грошових онлайн-операцій. За словами власників даних структур, 
фізичним особам, що досі не стикалися з такого типу транзакціями, ризиковано і технічно непросто здійснювати їх самостійно, саме тому подібного роду компанії беруть на себе роль своєрідного посередника, за що і отримують оплату у вигляді певних відсотків від загальної суми транзакції - подібно до звичайних банків (Bitkoin v Ukraini...).

Проте треба зауважити, що поряд 3 перевагами цифрові гроші мають також і певні недоліки (рис. 2).

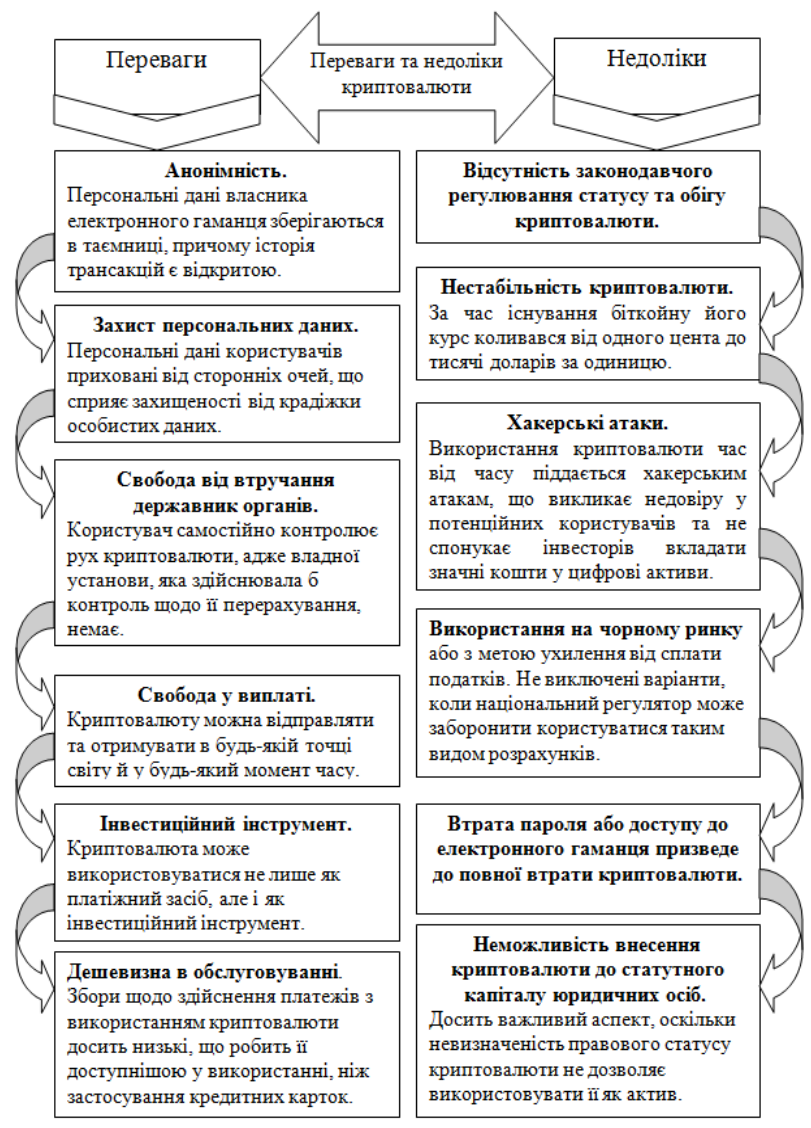

Рис. 2. Переваги та недоліки використання криптовалюти в економічній системі України

Джерело: побудовано авторами на основі (Skromna charivnist Bitkoina...; Chy buty kryptovaliuti na ukrainskomu rynku)

Сьогодні bitcoin продовжує свій розвиток, число користувачів цієї системи неухильно зростає в Українi. Популярність bitcoin також породила створення інших криптовалют, що розвиваються поряд з bitcoin, але іхня популярність і можливості поки набагато менша. У деяких країнах, в тому числі в Україні, 3 bitcoin почали боротися, пояснюючи це турботою про людей, застереженням їх від вкладення грошей в «грошові сурогати» і можливої їх втрати, якщо настав би крах bitcoin. Однак насправді така боротьба, найімовірніше, викликана бажанням сконцентрувати функції грошової емісії, а значить - і влади, в руках держави і не допустити утворення альтернативних джерел емісії платіжних засобів, оскільки вони не піддаються ніякому державному регулюванню.
НБУ в офіційних джерелах зазначив, що випуск віртуальної валюти bitcoin не має будь-якого забезпечення та юридично зобов'язаних за нею осіб, не контролюється державними органами влади жодної з країн. Отже, bitcoin $є$ грошовим сурогатом, який не має забезпечення реальної вартості.

Таким чином всі ризики з використанням для розрахунків криптовалют несе учасник таких розрахунків, натомість Національний банк України як регулятор не відповідає за можливі ризики та втрати, пов'язані із використанням bitcoin, а лише рекомендує користуватися послугами тільки тих платіжних систем, які внесені до Реєстру платіжних систем, систем розрахунків, учасників цих систем та операторів послуг платіжної інфраструктури.

Однак, незважаючи на чітку позицію НБУ і негативні відгуки про роботу системи, заперечувати міжнародний досвід та розвиток bitcoin у практиці міжнародних валютних розрахунків не варто. Так само як і не варто відмовлятися від використання електронних грошей через їх потенційну загрозу.

Звичайно, зараз в Україні використання криптовалют не досягло таких показників, як у США, країнах Західної Європи чи Південно-Східної Азії. Однак, незважаючи на те, що широка громадськість ще і досі мало знає про криптовалюти, в тому числі bitcoin, сьогодні Україна входить у топ-5 країн світу за кількістю користувачів різними bitcoin -гаманцями. Справа в тому, що bitcoin дуже популярні серед українських IT-фахівців, які дуже активно інвестують реальні гроші у віртуальну валюту.

UBR.ua вирішив вияснити, які компанії в Україні приймають bitcoin i що за них можна купити. 3 bitcoin в Україні працюють не більше ніж 20 компаній (табл.). За них можна придбати квитки на концерт, виставку, кіно, театр, цирк, дельфінарій, планетарій. Оплачувати ці послуги криптовалютою стало можливим $з$ жовтня 2015 року.

У 2016 році найбільша кількість пошукових запитів зі словом bitcoin надходило з Харкова, на другому місці - Дніпро, на третьому - Львів, на четвертому - Одеса. Київ замикає п’ятірку міст. Якщо дивитися статистику за областями, то на першому місці 3 великим відривом від решти - окупований Крим. Зацікавленість до криптовалюти пояснюється тим, що місцевому бізнесу важко здійснювати розрахунки із закордонними партнерами через дію санкцій.

3 грудня минулого року Українська біржа запустила торгівлю ф'ючерсними контрактами на індекс bitcoin. Специфікація контрактів зареєстрована в НКЦПФР. Це фактично перший регульований ринок у світі, який запропонував ф'ючерсні контракти на bitcoin.

у 2016 році юридична компанія Axon Partners стала першою українською компанією, що внесла bitcoin в свій статутний капітал, що свідчить про те що криптовалюта знаходить своє застосування в Україні. 
Компанії в Україні, які приймають розрахунки у bitcoin

\begin{tabular}{|l|l|}
\hline \multirow{3}{*}{} & Продуктовый магазин в Києві «Натуральні продукти» \\
\cline { 2 - 3 } & Сервісний центр Ukrainian iPhone Service, який знаходиться в Києві, з кінця 2014 року почав надавати послуги в \\
обмін на біткойни.
\end{tabular}

Джерело: побудовано авторами на основі (Kompanii v Ukraini...)

\section{Висновки}

На сьогодні значно зростає зацікавленість пересічних громадян у використанні криптовалюти, так само як зростає кількість компаній, які працюють 3 цією валютою. Досить багато проводиться спеціальних навчальних курсів для вивчення специфіки роботи 3 криптовалютою bitcoin.

На нашу думку, відбувається це на фоні масових банкрутств фінансових установ, відповідно втрат населенням своїх депозитних заощаджень, інфляція. Тому, з одного боку, інвестування в криптовалюту не видається таким ризикованим. Однак, з іншого боку, незважаючи на міжнародний досвід використання криптовалюти та численних іiі переваг, вважаємо за доцільне консультуватись 3 майнерами, досліджувати динаміку коливання bitcoin, врахувати те що хакери завжди розвиваються в одну епоху і крокують поряд 3 новими технологіями, тому необхідно добре зважувати усі застереження та інструкції щодо купівлі bitcoin. Утримуватися від розрахунків цією валютою в нашій країні, можна лише з міркувань відсутності відповідної інфраструктури для обміну криптовалюти в готівку для щоденного використання, а також існують обмеження в іiі використанні у сфері споживчих послуг. Проте у сфері консалтингу, інформаційних послуг та IT ймовірність оплати криптовалютою досить висока.

Саме тому першочерговим завданням $є$ розробка нормативно-правових актів на прикладі Данії, Англії, Нідерландів та інших країн, які вільно використовують криптовалюту bitcoin та широко впроваджують іiі для розрахунків.

Такі IT технології, як цифрова валюта, зрештою прийдуть в Україну і стануть способом взаєморозрахунків для більшості громадян. При відповідному їх вдосконаленні, законодавчому регулюванні та створенні інфраструктури ця технологія займе вагоме місце в повсякденному житті населення України.

Перспективи подальших досліджень. Використання системи bitcoin як варіант оплати товарів і послуг істотно розширює можливості ведення аграрного бізнесу, дає можливість проводити розрахунки за сільськогосподарську продукцію та послуги там, де немає банків та інших платіжних систем або ж комісії за банківське обслуговування надмірно високі (наприклад, в деяких країнах Азії). Головна і єдина умова - наявність інтернету. Разом $з$ тим, використання цієї системи в економічних розрахунках потребує популяризації іiі переваг над традиційними розрахунками та «адаптації» іï до кожного економічного регіону, в чому і полягають перспективи подальших досліджень цієї теми та наукових дебатів щодо іiі застосування в світовій аграрній економіці.

\section{Бібліографічні посилання}

Krupka, M.I. (2011). Hroshi ta kredyt: navch.pidruchnyk. [za red.d-ra ek. nauk, prof. M.I. Krupky]. Lviv: Vydavnychyi tsentr LNU im. Ivana Franka (in Ukrainian).

Gervais, A., Karame, G.O., Gruber, D., Capkun, S. (2015). On the Privacy Provisions of Bloom Filters in Lightweight Bitcoin clients. In ACSAC.

Brands, S. (1993). Untraceable off-line cash in wallets with observers (extended abstract). In CRYPTO.

Camenisch, J., Hohenberger, S., Lysyanskaya, A. (2005). Compact e-cash. - Eurocrypt.

Androulaki, E., Karame, G.O., Roeschlin, M., Scherer, T., Capkun, S. (2013). Evaluating User Privacy in Bitcoin. In Financial Cryptography.

Maxwell, G. (2013). CoinJoin: Bitcoin privacy for the real world. bitcointalk. org, August 2013.

Andrychowicz, M., Dziembowski, S., Malinowski, D., Mazurek, L. (2014). Secure Multiparty Computations on Bitcoin. In IEEE Symposium on Security and Privacy.

Courtois, N.T., Grajek, M., Naik, R. (2014). Optimizing in bitcoin mining. In Cryptography and Security Systems.

Bitkoin v Ukraini: [Elektronnyi resurs] Rezhym dostupu http://groshyki.com/bitcoin-v-ukrayini/ (in Ukrainian). 
Vartist Bitkoina zrosla do 1250 dolariv: [Elektronnyi resurs]. Rezhym dostupu https://hromadske.ua/posts/vartist-bitcoin-zrosla-do1250-dolariv Franka (in Ukrainian).

V Avstrii vidkryvsia pershyi $\mathrm{v}$ sviti Vitcoin bank: [Elektronnyi resurs] - Rezhym dostupu https://hromadske.ua/posts/v-avstrii-vidkryvsiapershyi-v-sviti-bitcoin-bank Franka (in Ukrainian).

Zakonodavcha nevrehulovanist prohresu: [Elektronnyi resurs] - Rezhym dostupu - http://yurgazeta.com/publications/practice/bankivske-tafinansovepravo/zakonodavcha-nevregulovanistprogresu.html Franka (in Ukrainian).

Kompanii v Ukraini, yaki pryimaiut rozrakhunky u bitkoinakh: [Elektronnyi resurs] - Rezhym dostupu http://ubr.ua/ukraine Franka (in Ukrainian).

Ofitsiinyi sait Natsionalnoho banku Ukrainy: Rezhym dostupu. - http://www.bank.gov.ua/control/uk/ publish/article?art_id=11879608 Franka (in Ukrainian).

Skromna charivnist Bitkoina: [Elektronnyi resurs] Rezhym dostupu - http://forbes.net.ua/ua/opinions/ 1428255-skromna-charivnist-bitkoina ukrayinski- realiyi-vikoristannya-kriptovalyut Franka (in Ukrainian).

Ukrainski kompanii pochynaiut vnosyty bitkoiny $\mathrm{v}$ statutnyi kapital: [Elektronnyi resurs] - Rezhym dostupu - http://forklog.com/ukrainskie-kompaniinachinayut-vnosit-bitkoin-v-ustavnoj-kapital Franka (in Ukrainian).

Forum Bitcoin: [Elektronnyi resurs] - Rezhym dostupu URL: http://bitlabs.ru/otnoshenie-k-bitkoin-v-raznyhstranah-mira Franka (in Ukrainian).

Khto zarobliaie na svitovomu skachku kryptovaliuty: [Elektronnyi resurs] - Rezhym dostupu http://biz.liga.net/all/it/stati/3412100-bitcoin-vukraine-kto-zarabotaet-na-mirovom-skachkekriptovalyuty.htm Franka (in Ukrainian).

Chy buty kryptovaliuti na ukrainskomu rynku: [Elektronnyi resurs] - Rezhym dostupu http://olans.com.ua/2017/02/20/chy-butykryptovaliuti-na-ukrainskomu Franka (in Ukrainian).

19 hrudnia vidbudetsia zapusk fiuchersnykh kontraktiv: [Elektronnyi resurs] - Rezhym dostupu http://www.fin.org.ua/news/1223260 Franka (in Ukrainian). 